\title{
Production of functional beer with the addition of probiotic: Saccharomyces boulardii
}

\author{
Produção de cerveja funcional com adição de probiótico: Saccharomyces boulardii \\ Producción de cerveza funcional con la adición de probiótico: Saccharomyces boulardii
}

Received: 01/20/2021 | Reviewed: 01/23/2021 | Accept: 01/26/2021 | Published: 02/03/2021

\author{
Amanda Felipe Reitenbach \\ ORCID: https://orcid.org/0000-0002-0517-6537 \\ Science of Beer Institute, Brazil \\ E-mail: amanda@scienceofbeer.com.br \\ Isabela Julio Iwassa \\ ORCID: https://orcid.org/0000-0002-2977-1103 \\ Universidade Estadual de Maringá, Brazil \\ E-mail: isa_iwassa@hotmail.com \\ Beatriz Cervejeira Bolanho Barros \\ ORCID: https://orcid.org/0000-0003-1191-4740 \\ Universidade Estadual de Maringá, Brazil \\ E-mail: beatrizbolanho@yahoo.com.br
}

\begin{abstract}
Industries have been investing in the development of functional products, such as the ones produced with probiotic microorganisms. The aim of this study was to develop a Pilsen-style beer with functional properties through the addition of the Saccharomyces boulardii probiotic. The beer was fermented with low-fermentation commercial yeast. The probiotic culture was added next, evaluating its probiotic potential. Microbiological, sensorial and physicochemical aspects were evaluated in the obtained products. The $S$. boulardii strain presented probiotic viability after the confirmation of the resistance to acid, bile salts and ethyl alcohol tests, maintaining superior levels of colonyforming to the indicated by the legislation during the 28 days storage. The beer with probiotic addition has not differed sensorially from the commercial beer concerning the aroma, flavor, general appearance and color. The results of sensorial, physicochemical and microbiological analysis showed the viability of the production of probiotic beer with the addition of $S$. boulardii.
\end{abstract}

Keywords: Yeasts; Probiotics; Sensory properties.

\section{Resumo}

As indústrias têm investido no desenvolvimento de produtos funcionais, como os produzidos com microrganismos probióticos. O objetivo deste estudo foi desenvolver uma cerveja do tipo Pilsen com propriedades funcionais por meio da adição do probiótico Saccharomyces boulardii. A cerveja foi fermentada com fermento comercial de baixa fermentação. A seguir, a cultura probiótica foi adicionada, avaliando seu potencial probiótico. Os aspectos microbiológicos, sensoriais e físico-químicos foram avaliados nos produtos obtidos. A cepa de $S$. boulardii apresentou viabilidade probiótica após a confirmação da resistência aos testes de ácido, sais biliares e álcool etílico, mantendo níveis de formação de colônias superiores aos indicados pela legislação durante os 28 dias de armazenamento. A cerveja com adição de probióticos não diferiu sensorialmente da cerveja comercial quanto ao aroma, sabor, aspecto geral e cor. Os resultados das análises sensoriais, físico-químicas e microbiológicas mostraram a viabilidade da produção de cerveja probiótica com a adição de $S$. boulardii.

Palavras-chave: Leveduras; Probióticos; Propriedades sensoriais.

\section{Resumen}

Las industrias han estado invirtiendo en el desarrollo de productos funcionales, como los producidos con microorganismos probióticos. El objetivo de este estudio fue desarrollar una cerveza estilo Pilsen con propiedades funcionales mediante la adición del probiótico Saccharomyces boulardii. La cerveza se fermentó con levadura comercial de baja fermentación. A continuación, se agregó el cultivo probiótico, evaluando su potencial probiótico. Se evaluaron aspectos microbiológicos, sensoriales y fisicoquímicos en los productos obtenidos. La cepa $S$. boulardii presentó viabilidad probiótica tras la confirmación de las pruebas de resistencia al ácido, sales biliares y alcohol etílico, manteniendo niveles de formación de colonias superiores a los indicados por la legislación durante los 28 días de almacenamiento. La cerveza con adición de probióticos no se ha diferenciado sensorialmente de la cerveza comercial en cuanto a aroma, sabor, apariencia general y color. Los resultados del análisis sensorial, fisicoquímico y microbiológico mostraron la viabilidad de la producción de cerveza probiótica con la adición de S. boulardii.

Palabras clave: Levaduras; Probióticos; Propiedades sensoriales. 


\section{Introduction}

Evidences suggest that the awareness of the consumer about health and well-being has increased greatly in recent times. In addition to that, it is known that food has a large potential in reducing the risk of diseases, which has caused an increase in the offer of functional foods in the market (Chrysochou, 2014; Krebs et al., 2018).

The intestinal microbiota affects several aspects related to human health (Ventura et al., 2018), performing an important role as modulators of metabolic responses and the immunological system (Duda-Chodak et al., 2015; Ventura et al., 2018). Probiotics have the capacity of altering the composition of the intestinal microbiota and preventing the growth of pathogenic bacteria (Almada et al., 2015). Therefore, probiotics are defined as organisms which, when administered in proper quantities, benefit the host's health (FAO/WHO, 2002).

The Saccharomyces boulardii is a very commonly yeast used as probiotic. This yeast can be commercialized as a dietetic supplement and it also presents several properties which confirm its effect as a probiotic agent, such as tolerance to the stomach acids and bile salts, besides the capacity of surviving body temperature $\left(37^{\circ} \mathrm{C}\right)$ and the intestinal tract's environment (McFarland, 2010; Kelesidis \& Pothoulakis, 2012). S. boulardii is used as a preventive and therapeutic source for the cure for diarrhea (McFarland, 2010; Rajkowska et al., 2012).

Beer is a popular beverage, widely consumed all over the world and, even not being so common, it can be an interesting food source or the providing of probiotics (Sohrabvandi et al., 2010). The beer industry has been developing new technologies for the production of beers which promote benefits to health such as functional beers, which are produced through the use of non-conventional ingredients that are able to produce or transform some production input into compounds which are beneficial to health (Basso et al., 2016).

Concerning this concept, this study aimed at developing a functional beer, with the addition of S. boulardii, assessing the cultivation of this strain as well as its probiotic potential. Besides that, we also verified the standard quality of the beer produced and its sensorial acceptance.

\section{Methodology}

\subsection{Cultivation of Saccharomyces boulardii and the fermentative process monitoring}

The preparation of Saccharomyces boulardii inoculum was realized according to Muller et al. (2007). The culture was obtained from the commercialized medicine Floratil@ (Merck), in which each $100 \mathrm{mg}$ capsule contains about 2x10 ${ }^{8}$ cells of Saccharomyces boulardii in freeze-dried form. The pre-inoculum was prepared in aseptic conditions, using $100 \mathrm{mg}$ of $S$.

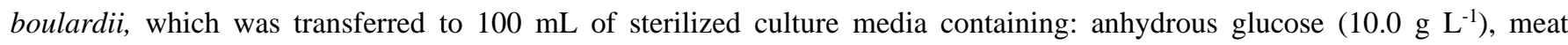
peptone $\left(2.0 \mathrm{~g} \mathrm{~L}^{-1}\right)$, yeast extract $\left(2.0 \mathrm{~g} \mathrm{~L}^{-1}\right)$, phosphate monopotassium $\left(0.60 \mathrm{~g} \mathrm{~L}^{-1}\right)$, urea $\left(0.36 \mathrm{~g} \mathrm{~L}^{-1}\right)$, ammonium sulfate $(0.12$ $\left.\mathrm{g} \mathrm{L}^{-1}\right)$, magnesium sulfate $\left(0.24 \mathrm{~g} \mathrm{~L}^{-1}\right)$ and water enough to complete $1 \mathrm{~L}$. After $12 \mathrm{~h}$, the optic density of the inoculum was measured to provide the cell concentration, adopting a minimum limit of $3.9 \mathrm{~g} \mathrm{~L}^{-1}$. For the cultivation, 12 Erlenmeyer bottles were prepared with $50 \mathrm{~mL}$ of solution $(45 \mathrm{~mL}$ of sterilized culture media and $5 \mathrm{~mL}$ of pre-inoculum) in a biologic-secure cabin. The fermentative process was monitored at initial time $\left(\mathrm{t}_{0}\right)$ and in $1 \mathrm{~h}$ intervals until the total time of $12 \mathrm{~h}$.

In order to determine the cell concentration, the method described by Schmidell et al. (2001) was used. The culture media $(10 \mathrm{~mL})$ were filtered in cellulose membranes of $0.80 \mu \mathrm{m}$ and dissected at $40{ }^{\circ} \mathrm{C}$ until a constant weight. The cell concentration was calculated by the relation between the mass of each dissected membrane and the volume of the filtered sample. The absorbance was measured in a spectrophotometer at $600 \mathrm{~nm}$, using the means of cultivation as white. A calibration curve was prepared with 0.01 to $0.60 \mathrm{~g} \mathrm{~L}^{-1}$ of cells $\left(\mathrm{R}^{2}=0.99\right)$. 
The glucose consumption was quantified by the 3,5-dinitrosalicylic acid method, as described by Miller (1959), being the absorbance read in spectrophotometer at $540 \mathrm{~nm}$. A standard curve prepared with glucose solutions - 0.1 to $1.0 \mathrm{~g} \mathrm{~L}^{-1}-$ was used $\left(\mathrm{R}^{2}=0.99\right)$.

For the quantification of the ethanol produced during cultivation, the extracts obtained at different times were filtered in membranes of $0.80 \mu \mathrm{m}$ (Sartorius) and the filtrate was analyzed by gas chromatography supplied with headspace injector. The chromatographic conditions were: oven temperature of $100{ }^{\circ} \mathrm{C}$ for 15 minutes, injector at $230{ }^{\circ} \mathrm{C}$; detector at $250{ }^{\circ} \mathrm{C}$; split: 1:10; dragging gas: hydrogen with flow rate of $1.0 \mathrm{~mL} \mathrm{~min}^{-1}$. The obtained data were treated by the Microquímica software. The calibration curve was obtained through solutions of ethanol in the concentrations of 0.5 to $5.0 \%(\mathrm{w} / \mathrm{w})\left(\mathrm{R}^{2}=0.99\right)($ Krebs et al., 2018).

The $\mathrm{pH}$ in the conducted experiments was determined in incubator agitator through the immersion of a $\mathrm{pH}$ meter electrode, after its calibration with standard solutions of pH 4.01 and 7.01 (Horwitz \& Latimer, 2005).

\subsection{S. boulardii strain test of resistance to $\mathrm{pH}$, bile e ethanol}

For the tolerance tests, the cells of $S$. boulardii were reactivated and cultivated as described in item 2.1 and analyzed according to Muller et al. (2007). The assessment of resistance to bile (at concentrations of 0.15, 0.2 and $0.3 \%$ of bile salts) and $\mathrm{pH}(1.0,2.0$ and 3.0 adjusted with chloridric acid) was realized by the plating surface methodology in potato dextrose agar (PDA) and incubated for at $30^{\circ} \mathrm{C}$. The plating was conducted or cultivation times of 30, 60 and 90 minutes. In order to assess the resistance to ethanol, absolute ethanol was added at concentrations of 1, 2, 3, 4 e $5 \%(\mathrm{v} / \mathrm{v})$. The samples were incubated in Shaker at $150 \mathrm{rpm}$ and $30^{\circ} \mathrm{C}$. The cultivation was carried on for $24 \mathrm{~h}$ and after this period, the previously described plating was conducted.

\subsection{Craft beer production}

The activation of the $S$. boulardii probiotic culture was realized by mixing $1 \mathrm{~g}$ of dry cell in a glucose solution $10 \mathrm{~g}$ $\mathrm{mL}^{-1}$ (previous autoclaved at $121{ }^{\circ} \mathrm{C}$ for $15 \mathrm{~min}$ ). The sachet of yeast was sterilized with gaze dipped in alcohol $70 \%$ and inoculated in a biological secure chamber. After the inoculation, the sample was taken to the incubator with agitation of 150 rpm at $30{ }^{\circ} \mathrm{C}$ for $3 \mathrm{~h}$ (Muller et al., 2007).

The wort used for the production of the probiotic beer was obtained at Heineken brewery Ponta Grossa (Paraná)'s unit. The wort used was the one from Pilsen beer, which was bottled in $600 \mathrm{~mL}$ capacity bottles, pasteurized at 10 UP (pasteurization unit) twice. Next, the wort was refrigerated $\left(2-6{ }^{\circ} \mathrm{C}\right)$ until the moment of usage. The experiments in beer production were conducted in an 8-liter capacity stainless steel bioreactor, which was connected to a thermostatic bath for control of fermentation temperature. The culture of low-fermentation beer yeast Saccharomyces cerevisiae w 34/70 (Fermentis ${ }^{\circledR}$ ) with a proportion of dry cell to worth of 1:1 $\left(\mathrm{g} \mathrm{L}^{-1}\right)$ was added to the Pilsen-type wort. The worth was aired by mechanical agitation for incorporating oxygen. The fermentation occurred at a controlled temperature of $15{ }^{\circ} \mathrm{C}$ for primary fermentation. The measure of ${ }^{\circ}$ Platô was checked every $8 \mathrm{~h}$ in order to verify its end. After the fermentation, the beer was bottled and pasteurized at $60{ }^{\circ} \mathrm{C}$ for $10 \mathrm{~min}$ (10 UP) (Rajkowska et al., 2012, Ceccaroni et al., 2018).

After the pasteurization, 5 to $10 \mathrm{~mL}$ of pre-activated probiotic culture were added to the beers which would be enriched with $S$. boulardii. Besides that, $7 \mathrm{~g} \mathrm{~L}^{-1}$ of glucose were added in order to maintain the fermentation of the culture, ensuring the production of $\mathrm{CO}_{2}$ in the final product (Rajkowska et al., 2012). The beers were stored in a refrigerator at $4{ }^{\circ} \mathrm{C}$. 


\subsection{Microbiological and physicochemical analysis of the produced beers}

Microbiological and physicochemical analyses of the samples were conducted in the period of 7, 14 and 28 days. The number of viable $S$. boulardii cells was quantified by surface plating in PDA culture media (Rajkowska et al., 2012).

The physicochemical analysis of the beers was carried according to AOAC (Horwitz \& Latimer, 2005): ethanol content (984.14), diacetyl (978.11), volatile acidity (935.23), moisture (method 925.09), ashes (method 923.03), protein (method 920.87), bitterness (method 970.11), pH (method 945.10), color (method 976.08), total and volatile acidity (method 945.08). Superior alcohols and esters were quantified by direct injection into a gas-liquid chromatography system (GC-2014; Shimadzu) and turbidity was determined in Hach 2100AN (Nephelometer, Hach Co, Loveland).

The original extract, total dry extract and defatted dry extract, apparent extract and degree of fermentation were calculated by using the Beer Calc software, from the Scandinavian School of Brewing (SSB), using the values obtained in the other conducted physical-chemical analysis (SSB, 2016).

\subsection{Sensorial Analysis}

To sensorial analysis the recommendation of Ramsey et al. (2018) was followed. Thus, 50 untrained tasters were recruited from the Federal University of Santa Catarina (UFSC) with ages ranging from 18 to 30 years old. The consumers' affective methods consisted in hedonic tests using a structured 9-points hedonic scale ranging from 1 (extremely disliked) to 9 (extremely liked). The evaluated attributes were: global appearance, aroma, flavor, body, acidity and color. The tasters received three codified beer samples $(\sim 50 \mathrm{~mL})$ at temperatures of 7 to $12{ }^{\circ} \mathrm{C}$, which were presented randomly in plastic cups codified with 3 digits. Three samples of beer were used: (A) Pilsen beer with no addition of probiotic, (B) Pilsen beer with addition of probiotic and (C) commercial Pilsen beer. The approval of the Ethical Committee in Research with Human of the Federal University of Santa Catarina was granted before the beginning of this analysis.

\subsection{Statistical Analysis}

The analysis of Variance (ANOVA) was conducted in order to detect statistically relevant differences for the sensorial attributes between the beers. The Tukey test $(\mathrm{p}<0.05)$ was conducted to compare the averages. The results were evaluated with the software EXCEL.

\section{Results and Discussion}

\subsection{S. boulardii cultivation kinetics}

Figure 1 presents the parameters evaluated in the S. boulardii cultivation kinetics with an initial concentration of $10 \mathrm{~g}$ $\mathrm{L}^{-1}$ in the period of $12 \mathrm{~h}$. The evaluated parameters were cellular concentration (X), glucose consumption (S) and production of ethanol concentration of $10 \mathrm{~g} \mathrm{~L}^{-1}$ in the period of $12 \mathrm{~h}$. It can be observed that $S$. boulardii presented a velocity of growth in exponential stage ( 2 to $4 \mathrm{~h}$ ) in which the curve had an acute inclination due to favorable factors and conditions for the metabolism, where cellular growth is at maximum. After that, the growth becomes linear during the $12 \mathrm{~h}$ of the fermentative process, which indicates the presence of residual glucose. Another possible factor for the reducing of cellular growth is the production of ethanol, as observed by Sulieman et al. (2018) in the fermentation of S. cerevisae. 
Figure 1. Cellular concentration $\left(\mathrm{X}-\mathrm{g} \mathrm{L}^{-1}\right)$, concentration of consumed glucose $\left(\mathrm{S}-\mathrm{g} \mathrm{L}^{-1}\right)$ and alcohol production $(\% \mathrm{v} / \mathrm{v})$ of S. boulardii cultivation

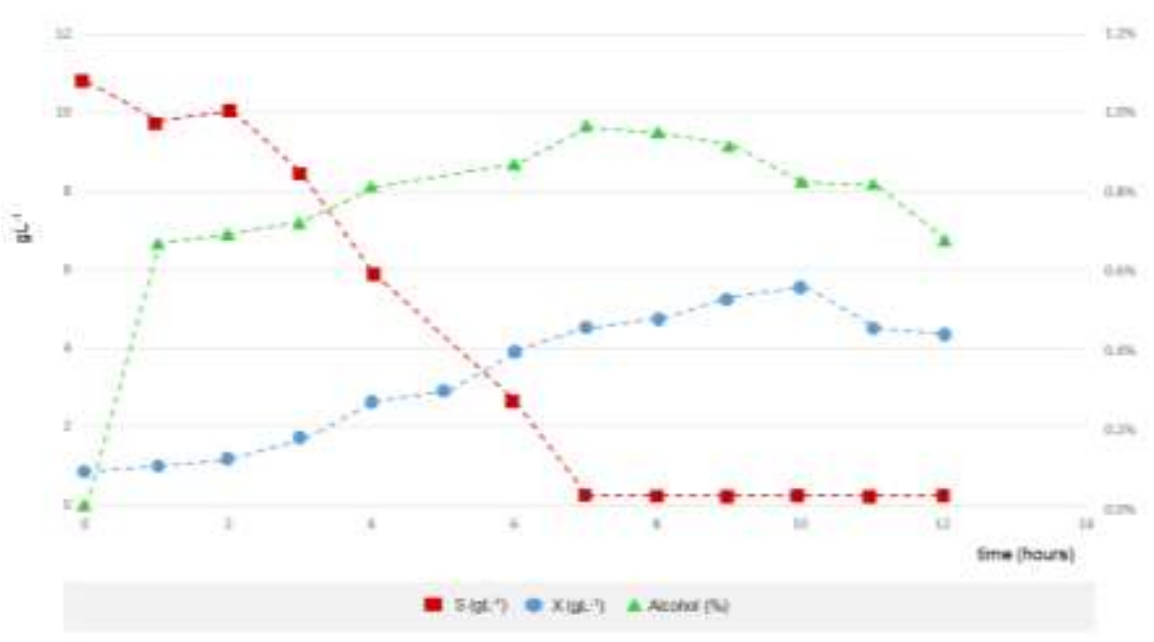

Source: Authors

In the early stages of the fermentation process, glucose was used essentially for cultivation. The consumption of the substrate was practically total in $12 \mathrm{~h}$ of fermentation of $S$. boulardii. Putra et al. (2013) observed the same for the fermentative process of $S$. cerevisae in $28 \mathrm{~h}$. The production of ethanol started dropping after $7 \mathrm{~h}$ of fermentation. The consumption of ethanol, glycerol and other organic acids happen due to metabolic oxidation by the cell during the fermentative process in order to generate more ATP and biomass, but only in aerobiosis (Schmidell et al., 2001).

Figure 2 presents the results for the analysis of the $\mathrm{pH}$ during the fermentative process of the $S$. boulardii, which indicate a decrease in the values in the $12 \mathrm{~h}$ of fermentation. A study of the growth of S. boulardii has reported the same behavior for the parameter $\mathrm{pH}$ in $12 \mathrm{~h}$ of process (Muller et al., 2007).

Figure 2. Results of the $\mathrm{pH}$ parameter of the experiments of $S$. boulardii cultivation

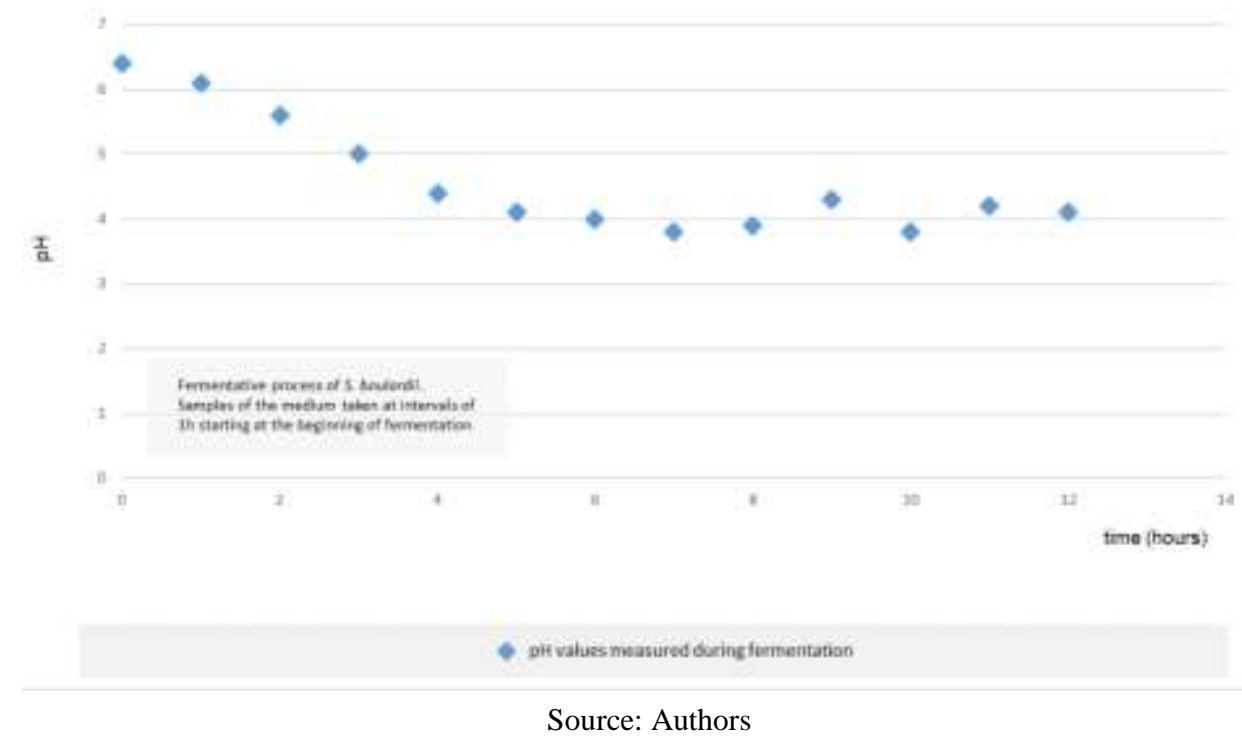

Ribéreau-Gayon and Peynaud (1996) reported that the pH may possibly decrease due to the formation of organic acids (succinic, lactic, acetic and other acids) with a consequent increase of the acidity of the fermentation media. 


\subsection{Resistance of the S. boulardii to $\mathrm{pH}$, bile salts and ethanol}

To perform its probiotic effect, it is necessary that the bacteria or yeast reaches the host's gastrointestinal tract at high enough levels to play this role. Therefore, it is necessary that a probiotic is tolerant to oxygen, acid media, bile and heat. The standards show that probiotic products must have at least $10^{6}$ viable microorganisms per millimeter (Stack et al., 2010; Franz \& Holzapfel, 2011; Zoumpopoulou et al., 2017).

S. boulardii reached values higher than $10^{6} \mathrm{UFC} \mathrm{mL}^{-1}$ in all the tested $\mathrm{pH}$ values, as shown in Table 1 . The results demonstrate that during the first $30 \mathrm{~min}$ of exposition, the counting grew in all tested $\mathrm{pH}$ strips. A study with Lactobacillus acidophilus NIT reported that, in $60 \mathrm{~min}$ of exposition to $\mathrm{pH} 2$, there was a $20 \%$ survival rate of the bacteria. However, this number dropped to an undetectable level in $120 \mathrm{~min}$. On the other hand, on $\mathrm{pH} 3$, the percentage of survival was larger in the entire process (Pan et al., 2009).

Table 1. S. boulardii count after exposition to environment acidified with $\mathrm{HCl}$ and bile salts for 30, 60 and 120 minutes.

\begin{tabular}{cccc|ccc}
\hline \multirow{2}{*}{ Time (min) } & \multicolumn{5}{c}{ S. boulardii count $\left(\log {\left.\mathrm{UFC} \mathrm{mL}^{-1}\right)}\right.$} \\
\cline { 2 - 7 } & \multicolumn{3}{c}{$\mathrm{pH}$} & \multicolumn{3}{c}{ Bile (\%) } \\
\hline & 1.0 & 2.0 & 3.0 & 0 & 0.2 & 0.3 \\
\hline 30 & 6.63 & 7.59 & 7.77 & 7.96 & 7.43 & 6.91 \\
60 & 6.79 & 8.05 & 8.03 & 8.72 & 8.05 & 7.30 \\
90 & 7.04 & 9.05 & 9.05 & 9.77 & 9.46 & 8.46 \\
\hline
\end{tabular}

Source: Authors

The capacity to resist bile is one of the most important properties that determine if the bacteria can survive in the small intestine and, consequently, its probiotic potential (Bustos et al., 2018). The data presented on Table 1 show that the analyzed strain presented resistance to bile salts, with a decrease of only one logarithm cycle after the 90 min exposition to bile salts at 0.2 and $0.3 \%$. Andriantsoanirina et al. (2013) studied the resistance of different species of Bifidobacterium spp and observed that $B$. breve and $B$. adolescentis presented the highest number of moderately bile-resistant strains. Besides that, another study reported that Lactobacillus isolates have resistance higher than 50\% in concentrations of $0.15,0.3$ and $0.45 \%$ of bile salt (Kumar \& Kumar, 2015).

The results demonstrate that the $S$. boulardii strain's growth was proportional to the increase of the ethanol concentration, being the values $14.27,14.69,15.48,17.27,17.69 \mathrm{Log} \mathrm{UFC} \mathrm{mL}^{-1}$ at $1,2,3,4$ and $5 \%$ of ethanol, respectively. These results confirm the S. boulardii resistance in the conditions studied. Stewart (2014) affirms that one of the main characteristics of the Saccharomyces is its high tolerance to high concentrations of ethanol. In addition to that, the author highlights that the resistance of different strains of S. cerevisiae may vary, but the largest majority is able to grow in beverages with 8 to $12 \%$ alcohol (v/v).

Finally, the $S$. boulardii strain presented probiotic viability after confirmation of the resistance to acid, bile salts and ethyl alcohol. Therefore, this strain is a candidate to probiotic cultures in alcoholic fermentation products. 


\subsection{Analysis of the beer's quality standards}

The beer produced with probiotics had similar visual qualities to Pilsen craft beers, which is due to the fact that neither has been through the filtering process after the fermentation and both contained cells in suspension. Results of the counting of S. boulardii during a 28-day storage, as demonstrated in Table 2, have shown decreasing values until the 21st day of storage, with the reduction of about one logarithmic cycle on the final counting of time. All the obtained values are considered satisfactory for the product to be considered probiotic because, according to Nag \& Das (2013), the minimum number of probiotic bacteria at the moment of ingestion must be $\geq 10^{6} \mathrm{UFC} \mathrm{g}^{-1}$ in order to achieve therapeutic effects. A study of supplementation of soy yoghurt with extracts and mulberry leaves shows that, after 30 days, the quantities of $L$. casei 01 and L. acidophilus LA5 stayed above $6 \log _{10} \mathrm{UFC} \mathrm{g}^{-1}$ (Kemsawasd \& Chaikham, 2018).

Table 2. Counting of probiotic beer during a 28-day storage time.

\begin{tabular}{cc}
\hline Days & S. boulardii count $\left(\log {\left.\mathrm{UFC} \mathrm{mL}^{-1}\right)}^{-14.22}\right.$ \\
\hline 1 & 17.27 \\
14 & 19.40 \\
21 & 20.89 \\
28 & 19.69 \\
\hline
\end{tabular}

Source: Authors

For comparison purposes, physicochemical analysis was carried on the beers with and without the addition of probiotic culture and the results were expressed in Table 3. The alcohol content of the samples varied between 4.70 and $6.06 \%$, being superior to the ones reported by Ceccaroni et al. (2018) for gluten-free rice-malted beer (4.80\%). Among the parameters demanded by legislation, the alcohol content is the only one that must be declared on the product's label (Brasil, 1997).

The samples of beer with and without the addition of probiotics had $\mathrm{pH}$ values of 4.57 and 4.60 , respectively. These values are similar to the ones reported by Ramsey et al. (2018) for beers with different percentages of alcohol (4.17 to 4.20). Most beers present $\mathrm{pH}$ between 3.9 and 4.6 and their safety is connected to that as well as to the presence of ethanol, anaerobic conditions and the presence of antimicrobial agents, such as iso- $\alpha$-acids (Bamforth, 2008). The average acidity of the samples varied from 1.6 to $2.0 \mathrm{~g}$ of lactic acid by $100 \mathrm{~mL}$ of sample. In the Brazilian legislation, there is no mention of maximum permitted acidity or $\mathrm{pH}$ for beer. 
Table 3. Physicochemical analysis of beers with and without addition of probiotic culture after a 28-day period of storage

\begin{tabular}{|c|c|c|c|}
\hline Analysis & Specification & Beer without probiotics & Beer with probiotics \\
\hline Alcohol & $\% \mathrm{v} \mathrm{v}^{-1}$ & 5.79 & 6.06 \\
\hline Volatile acidity & $\mathrm{m} \mathrm{Eg} \mathrm{L}{ }^{-1}$ & 1.60 & 2.00 \\
\hline Dry defatted extract & g $100 \mathrm{~mL}^{-1}$ & 5.25 & 5.03 \\
\hline Total extract & g $100 \mathrm{~mL}^{-1}$ & 5.25 & 5.03 \\
\hline Protein & g $100 \mathrm{~mL}^{-1}$ & 0.48 & 0.40 \\
\hline Fixed mineral residue & g $100 \mathrm{~mL}^{-1}$ & 0.16 & 0.14 \\
\hline $\mathrm{pH}$ & g $100 \mathrm{~mL}^{-1}$ & 4.57 & 4.60 \\
\hline Primitive extract & ${ }^{\circ} \mathrm{P}$ & 14.67 & 14.49 \\
\hline Real extract & ${ }^{\circ} \mathrm{P}$ & 6.06 & 5.45 \\
\hline Apparent extract & ${ }^{\circ} \mathrm{P}$ & 4.07 & 3.36 \\
\hline Limit extract & ${ }^{\circ} \mathrm{P}$ & 2.93 & 2.83 \\
\hline Fermented extract & ${ }^{\circ} \mathrm{P}$ & 1.14 & 0.53 \\
\hline Color & $\mathrm{EBC}$ & 8.60 & 9.00 \\
\hline Bitterness & $\mathrm{BU}$ & 7.00 & 7.50 \\
\hline Acetaldehyde & $\operatorname{mg~L}{ }^{-1}$ & 8.10 & 9.80 \\
\hline Ethyl acetate & $\mathrm{mg} \mathrm{L}^{-1}$ & 16.40 & 9.60 \\
\hline Isoamyl acetate & $m g \mathrm{~L}^{-1}$ & 1.28 & 0.39 \\
\hline Hexanoate of ethyl & $m g L^{-1}$ & 0.23 & 0.25 \\
\hline Total superior alchohols & $\mathrm{mg} \mathrm{L}^{-1}$ & 89.50 & 96.80 \\
\hline DMS & $\mu g \mathrm{~L}^{-1}$ & 16.00 & 15.00 \\
\hline Free diacetyl & $\mu \mathrm{g} \mathrm{L}^{-1}$ & 39.00 & 45.00 \\
\hline Total free VDK & $\mu g \mathrm{~L}^{-1}$ & 53.00 & 52.00 \\
\hline$\mu \mathrm{g} \mathrm{L}^{-1}$ & 4.00 & 4.00 & \\
\hline
\end{tabular}

Source: Authors

Values for the color parameter of the beers with and without the addition of probiotics were obtained. They were respectively 8.6 and 9.0 EBC, being a little darker when compared to Lager beers submitted to the ultrasound treatment (3.6 a $4.5 \mathrm{EBC}$ ) (Deng et al., 2018). The beers are classified by the Brazilian legislation as light-colored (EBC<20) or dark (EBC>20) (Brazil, 1997). Deng et al. (2018) even obtained a bitterness interval of 10.28 to 11.42 BU, the beers from this study being the most bitter (7.0 to 7.5 BU). In order to provide aroma and bitterness to the beer, hops are added to the wort and this 
process leads to the formation of compounds considered to be the main source of bitterness of the beer as, for example, the iso$\alpha$-acids. Therefore, the intensity of bitterness is due to the level of iso- $\alpha$-acids present in the beers (Schönberger \& Kostelecky, 2011).

Amongst all the aromatic compounds that can dramatically contribute to the beer flavor, the esters and superior alcohols are the ones found in the largest quantities. Both beers with and without the addition of probiotic culture presented total superior alcohol values of 89.5 and $96.8 \mathrm{mg} \mathrm{L}^{-1}$, respectively. Moreover, esters like ethyl acetate, isoamyl acetate and ethyl hexanoate provide fruity flavor to the beer (He et al., 2014). The rate of acetaldehyde of both samples was high, which might be related to the fact that the beer having incorporated little oxygen after the inoculation stage.

Concerning the real extract, beers with or without the addition of probiotic culture had percentages of 6.06 and $5.45 \%$ respectively. These percentages were lower to the ones reported by Cimini \& Moresi (2018) for two beers of different types (3.90 and 5.80\%). These differences might possibly be explained by technological variations, such as a greater use of malt.

\subsection{Sensorial Analysis}

The results of the sensorial test, expressed in the Table 4, showed that the beer with the addition of probiotics had superior averages than the beer without probiotics in the attributes flavor, aroma and global appearance, not differing from the commercial beer $(\mathrm{p}<0.05)$. These results show that the craft beer produced without the addition of $S$. boulardii had the lowest acceptance by the consumers. This is probably due to the production of undesirable aromas by the low-fermentation yeast. As for the body and acidity attributes, the craft formulations (with or without probiotics) registered inferior averages than the ones obtained for the commercial beers, which might be related to the fact that they are a more familiar product to the tasters, presenting more pleasant characteristics in these parameters.

Table 4. Sensorial analysis for craft beers with and without probiotics and for commercial beer.

\begin{tabular}{|c|c|c|c|c|}
\hline Attribute & Beer without probiotics & Beer with probiotics & Commercial beer & Tukey's MDS \\
\hline Flavor & $5.08^{\mathrm{a}}$ & $6.12^{\mathrm{b}}$ & $7.00^{\mathrm{b}}$ & 0.98 \\
\hline Aroma & $5.18^{\mathrm{a}}$ & $6.88^{\mathrm{b}}$ & $6.82^{\mathrm{b}}$ & 1.02 \\
\hline Color & $5.92^{\mathrm{a}}$ & $6.47^{\mathrm{a}}$ & $6.53^{\mathrm{a}}$ & 0.97 \\
\hline Body & $5.35^{\mathrm{a}}$ & $6.29^{\mathrm{a}}$ & $6.41^{\mathrm{b}}$ & 0.97 \\
\hline Global appearance & $5.65^{\mathrm{a}}$ & $6.67^{\mathrm{b}}$ & $6.94^{\mathrm{b}}$ & 0.88 \\
\hline Acidity & $5.25^{\mathrm{a}}$ & $5.71^{\mathrm{a}}$ & $6.73^{\mathrm{b}}$ & 0.96 \\
\hline
\end{tabular}

*Averages followed by the same letter (on each line) have not differed statistically ( $p>0.05)$. Source: Authors.

Among the sensorial parameters evaluated (Table 4), only the attribute of color had no difference among the samples ( $p>0.05$ ), which shows that the beers have not presented enough color difference to be noticed by the tasters, probably because they were all produced from the same type of wort.

The acceptance averages varied from 5.08 (without probiotics) and 7.00 (commercial), with "indifferent" and "liked moderately" being in the hedonic points. Di Monaco et al. (2004) suggests that this behavior happens when the tasters are not familiar with the samples' identity, not being able to tell the difference between the verified samples thus establishing their preference in the intermediary part of the scale. 
Figure 3 shows the frequency of grades obtained in the acceptance test for the beer samples. It can be observed on the histogram that the commercial beer was the one which presented the highest frequency of grades on the positive side. However, the beer with the addition of probiotic culture obtained near averages for the same attributes.

Figure 3. Frequency of global acceptance grades of the beer without probiotics, with probiotics and commercial with a hedonic scale of 9 points. Based on the results, it can be said that the probiotic culture has particular properties which allow it to be used for the production of a quality Pilsen-style beer.
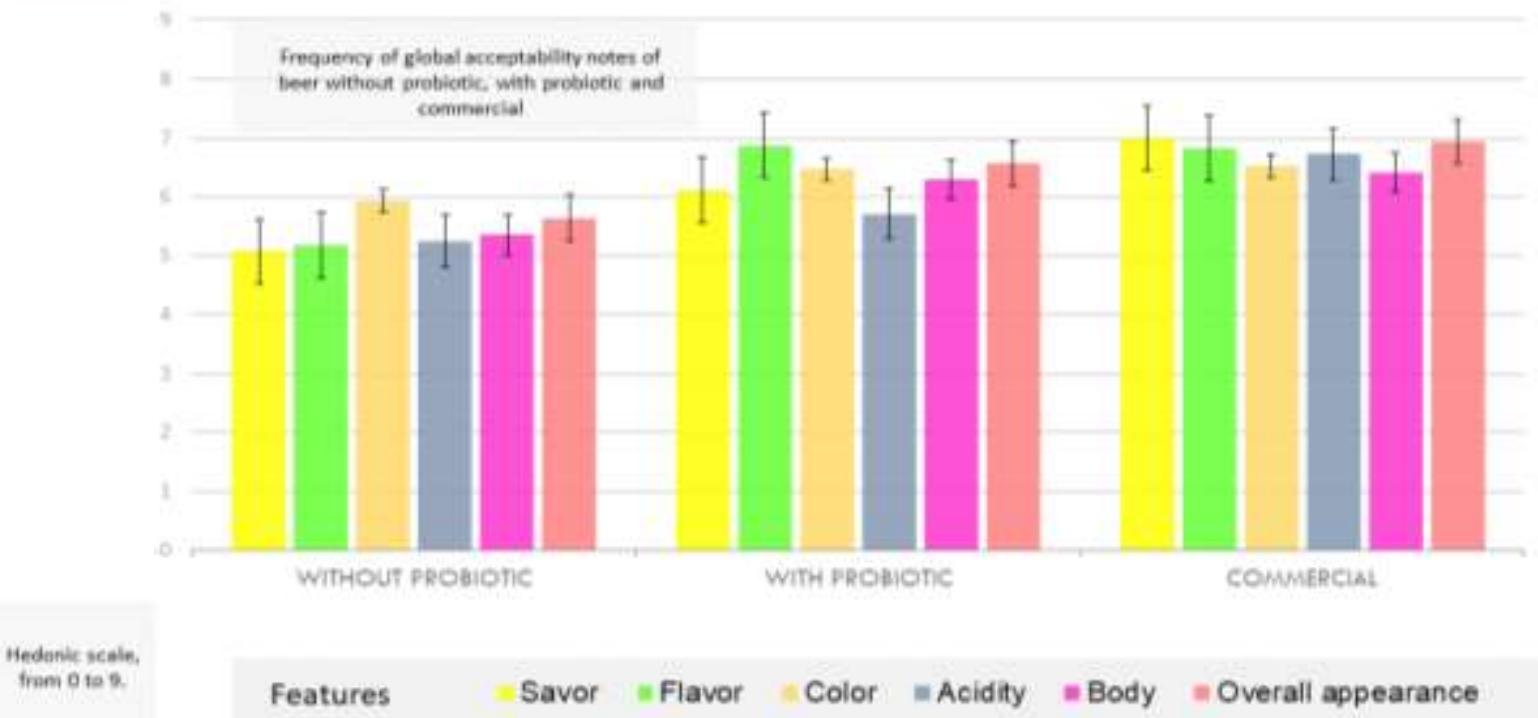

Source: Authors

\section{Conclusion}

The probiotic culture of Saccharomyces boulardii have was able to survive in the studied conditions of resistance (pH, bile acids) and its use to beer production is in accordance to the expected physical-chemical and microbiological standards. Besides that, the viability of the probiotic culture was verified for 28 days, with a cell count superior to $10^{6} \mathrm{UFC}^{-1}$. The sensorial analysis showed a good acceptance level for the produced beer, especially for the attribute's aroma, flavor, global appearance and color. The obtained results have pointed out that the beer with the addition of probiotic culture presents viability for industrial scale production. Further studies could be conducted to know how the regular consumption of probiotic beer affects the consumer's health.

\section{References}

Almada, C. N., Martinez, R. C. \& Sant'Ana, A. S. (2015). Characterization of the intestinal microbiota and its interaction with probiotics and health impacts. Applied Microbiology and Biotechnology, 99 (1), 4175-4199.

Andriantsoanirina, V., Allano, S., Butel, M. J. \& Aires, J. (2013). Tolerance of Bifidobacterium human isolates to bile, acid and oxygen. Anaerobe, 21 (1), 3942.

Bamforth, C. (2008). Food, Fermentation and Microorganisms. John Wiley \& Sons.

Basso, R. F., Alcarde, A. R. \& Portugal, C. B. (2016). Could non-Saccharomyces yeasts contribute on innovative brewing fermentations? Food Research International, $86(1), 112-120$.

Brasil, Ministério da Agricultura. Secretaria Nacional de Defesa Agropecuária (1997). Decreto $n^{\circ} 2.314$, de 4 de setembro de 1997.Diário oficial da União.

Bustos, A. Y., De Valdez, G. F., Fadda, S. \& Taranto, M. P. (2018). New insights into bacterial bile resistance mechanisms: the role of bile salt hydrolase and its impact on human health. Food Research International, 112 (1), 250-262. 
Ceccaroni, D., Sileoni, V., Marcon, O., De Francesco, G., Lee, E. G. \& Peretti, G. (2018). Specialty rice malt optimization and improvement of rice malt beer aspect and aroma. LWT-Food Science and Technology, 99 (1), 299-305.

Chrysochou, P. (2014). Drink to get drunk or stay healthy? Exploring consumers' perceptions, motives and preferences for light beer. Food Quality and Preference, 31 (1), 156-163.

Cimini, A. \& Moresi, M. (2018). Combined enzymatic and crossflow microfiltration process to assure the colloidal stability of beer. LWT - Food Science and Technology, 90 (1), 132-137.

Deng, Y., Bi, H., Yin, H., Yu, J., Dong, J., Yang, M. \& Ma, Y. (2018). Influence of ultrasound assisted thermal processing on the physicochemical and sensorial properties of beer. Ultrasonics Sonochemistry, 40 (1), 166-173.

Di Monaco, R., Cavella, S., Di Marzo, S. \& Masi, P. (2004). The effect of expectations generated by brand name on the acceptability of dried semolina pasta. Food Quality and Preference, 15 (5), 429-437.

Duda-Chodak, A., Tarko, T., Satora, P. \& Sroka, P. (2015). Interaction of dietary compounds, especially polyphenols, with the intestinal microbiota: A review. European Journal of Nutrition, 54 (3), 325-341.

FAO/WHO. (2002). Evaluation of health and nutritional properties of probiotics in food including powder milk with live lactic acid bacteria Avaliable in: http://www.fao.org. (Acessed 15 November 2018).

Franz, C. M. A. P. \& Holzapfel, W. H. (2011). The Importance of Understanding the Stress Physiology of Lactic Acid Bacteria. In: Tsakalidou, E. \& Papadimitriou, K. (eds) Stress Responses of Lactic Acid Bacteria. Food Microbiology and Food Safety, Springer.

He, Y., Dong, J., Yin, H., Chen, P., Lin, H. \& Chen, L. (2014). Monitoring of the production of flavour compounds by analysis of the gene transcription involved in higher alcohol and ester formation by the brewer's yeast Saccharomyces pastorianus using a multiplex RT-qPCR assay. Journal of the Institute Brewing, 120 (2), 119-126.

Horwitz, W. \& Latimer, G. (2005). Official methods of analysis of AOAC International (18th ed). Gaithersburg: AOAC International.

Kelesidis, T. \& Pothoulakis, C. (2012). Efficacy and safety of the probiotic Saccharomyces boulardii for the prevention and therapy of gastrointestinal disorders. Therapeutic Advances in Gastroenterology, 5 (2), 111-125.

Kemsawasd, V. \& Chaikham, P. (2018). Survival of probiotics in soy yoghurt plus mulberry (c.v. Chiang Mai 60) leaf extract during refrigerated storage and their ability to tolerate gastrointestinal transit. LWT-Food Science and Technology, 93 (1), 94-101.

Krebs, G., Muller, M., Becker, T. \& Gastl, M. (2018). Characterization of the macromolecular and sensory profile of non-alcoholic beers produced with various methods. Food Research International, 166 (1), 508-517.

Kumar, A. \& Kumar, D. (2015). Characterization of Lactobacillus isolated from dairy samples for probiotic properties. Anaerobe, 33 (1), 117-123.

McFarland, L. V. (2010). Systematic review and meta-analysis of Saccharomyces boulardii in adult patients. World Journal of Gastroenterology, 16 (18), 2202-2222.

Miller, G. L. (1959). Use of dinitrosalicylic acid reagent for determination of reducing sugars. Analytical Chemistry, 31 (3), $426-428$.

Muller, J. L., Protti, K. L., Machado, M. S., Lacerda, L. L. V., Bresolin, T. M. B. \& Podlech, P. S. (2007). Comparison of Saccharomyces boulardii growth in an air-lift fermentor and in a shaker. Food Science and Technology, 27 (4), 688-693.

Nag, A. \& Das, S. (2013). Improving ambient temperature stability of probiotics with stress adaptation and fluidized bed drying. Journal of Functional Foods, $5(1), 170-177$.

Pan, X., Chen, F., Wu, T., Tang, H. \& Zhao, Z. (2009). The acid, bile tolerance and antimicrobial property of Lactobacillus acidophilus NIT. Food Control, 20 (6), 598-602.

Putra, M. D., Abasaeed, A. E., Al-Zahrani, S. M., Gaily, M. H., Sulieman, A. K., Zeinelabdeen, M. A. \& Atiyeh, H. K. (2013). Production of fructose from highly concentrated date extracts using Saccharomyces cerevisiae. Biotechnology Letter, 36 (3), 531-536.

Rajkowska, K., Kunicka-Styczynska, A. \& Rygala, A. (2012). Probiotic Activity of Saccharomyces cerevisiae var. boulardii Against Human Pathogens. Food Technology and Biotechnology, 50 (2), 230-236.

Ramsey, I., Ross, C., Ford, R., Fisk, I., Yang, Q., Gomez-Lopez, J. \& Hort, J. (2018). Using a combined temporal approach to evaluate the influence of ethanol concentration on liking and sensory attributes of lager beer. Food Quality and Preference, 68 (1), 292-303.

Ribéreau-Gayon, J. E. \& Peynaud, E. (1996). Análise e controllo del vini. Bologna: Agricole.

Schmidell, W., Lima, U. A., Aquarone, E. \& Borzani, W. (2001). Biotecnologia Industrial. Engenharia Bioquímica. Edgard Blücher Ltda.

Schönberger, C. \& Kostelecky, T. (2012). 125 ${ }^{\text {th }}$ Anniversary Review: The Role of Hops in Brewing. Journal of the Institute of Brewing, 117 (3), $259-267$.

Sohrabvandi, S., Razavi, S. H., Mousavi, S. M. \& Mortazavian, A.M. (2010). Viability of Probiotic Bacteria in Low Alcohol- and NonAlcoholic Beer During Refrigerated Storage. Philippine Agricultural Scientist, 93 (1), 24-28.

SSB - Scandinavian School of Brewing (2016). Available in: www.beercalc.com.

Stack, H. M., Kearney, N., Stanton, C., Fitzgerald, G. F. \& Ross, R. P. (2010). Association of Beta-Glucan Endogenous Production with Increased Stress Tolerance of Intestinal Lactobacilli. Applied and Environmental Microbiology, 76 (2), 500-507. 
Research, Society and Development, v. 10, n. 2, e5010212211, 2021

(CC BY 4.0) | ISSN 2525-3409 | DOI: http://dx.doi.org/10.33448/rsd-v10i2.12211

Stewart, G. G. (2014). Saccharomyces cerevisiae. Encyclopedia of Food Microbiology, 2 (1), 309-315.

Sulieman, A. K., Putra, M. D., Abasaeed, A. E., Gaily, M. H., Al-Zahrani, S. M. \& Zeinelabdeen, M. A. (2018). Kinetic modeling of the simultaneous production of ethanol and fructose by Saccharomyces cerevisiae. Electronic Journal of Biotechnology, 34 (1), 1-8.

Ventura, M., O'Toole, P. W., De Vos, W. M. \& Van Sinderen, D. (2018) Selected aspects of the human gut microbiota. Cellular and Molecular Life Sciences, $75(1), 81-82$.

Zoumpopoulou, G., Pot, B., Tsakalidou, E, \& Papadimitriou, K. (2017). Dairy probiotics: Beyond the role of promoting gut and immune health. International Dairy Journal, 67 (1), 46-60. 